\title{
Ethnic Group Code
}

National Cancer Institute

\section{Source}

National Cancer Institute. Ethnic Group Code. NCI Thesaurus. Code C93563.

A coded value specifying the self-declared ethnic origination, independent of racial

origination. 